\title{
Note on Style and Abbreviations
}

All dates in the body of the text retain Old Style dating for day and month, but the year is changed to New Style. All dates in the footnotes are given as they appear in the source cited, but if the New Style year differs from that of the Old Style, the New Style year is added in brackets. All names in the body of the text are given their modern spelling, but names in the footnotes are given as they appear in the source cited. All quotations are given as they appear in the original, except ampersands which are replaced by "and."

The following abbreviations are used:

Abbott Abbott collection of parliamentary papers in the British Library

Add. MSS Additional Manuscripts

A.O. Archives Office

B.L. British Library

B.I.H.R. Bulletin of the Institute of Historical Research

CSPD Calendar of State Papers Domestic

HMC Publications of the Historical Manuscripts Commission

P.R.O. Public Record Office

R.O. Record Office 
